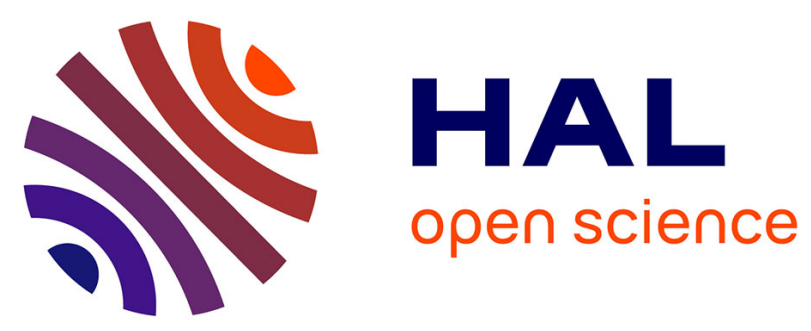

\title{
Commodities risk premia and regional integration in gas-exporting countries
}

\author{
Ilyes Abid, Khaled Guesmi, Stéphane Goutte, Christian Urom, Julien
}

Chevallier

\section{- To cite this version:}

Ilyes Abid, Khaled Guesmi, Stéphane Goutte, Christian Urom, Julien Chevallier. Commodities risk premia and regional integration in gas-exporting countries. Energy Economics, 2019, 80, pp.267-276. 10.1016/j.eneco.2018.12.027 . halshs-02148921

\section{HAL Id: halshs-02148921 \\ https://shs.hal.science/halshs-02148921}

Submitted on 21 Oct 2021

HAL is a multi-disciplinary open access archive for the deposit and dissemination of scientific research documents, whether they are published or not. The documents may come from teaching and research institutions in France or abroad, or from public or private research centers.
L'archive ouverte pluridisciplinaire HAL, est destinée au dépôt et à la diffusion de documents scientifiques de niveau recherche, publiés ou non, émanant des établissements d'enseignement et de recherche français ou étrangers, des laboratoires publics ou privés.

\section{다)(1) $(5$}

Distributed under a Creative Commons Attribution - NonCommercial| 4.0 International 


\title{
Commodities risk premia and regional integration in gas-exporting countries
}

\author{
Ilyes Abid ${ }^{\mathrm{a}}$, Khaled Guesmi ${ }^{\mathrm{b}, \mathrm{g}}$, Stéphane Goutte ${ }^{\mathrm{c}, \mathrm{d}}$, Christian Urom ${ }^{\mathrm{c}, \mathrm{e}}$, Julien Chevallier ${ }^{\mathrm{c}, \mathrm{f}, *}$ \\ a ISC Paris Business School, Paris, France \\ ${ }^{\mathrm{b}}$ Environment, Climate Change and Energy Transition Chair, IPAG Business School, Paris, France \\ ${ }^{c}$ Université Paris 8 (LED), 2 rue de la liberté, 93526 Saint-Denis cedex, France \\ dParis School of Business (PSB), 59 Rue Nationale, 75013, Paris, France \\ ${ }^{\mathrm{e}}$ Alex Ekwueme Federal University, Ndufu-Alike Ikwo, Nigeria \\ ${ }^{\mathrm{f}}$ IPAG Business School (IPAG Lab), 184 boulevard Saint Germain, 75006 Paris, France. \\ ${ }^{\mathrm{g}}$ Telfer School of Management, University of Ottawa, Canada
}

\section{A R T I C L E I N F O}

\section{Article history:}

Received 19 June 2018

Received in revised form 2 December 2018

Accepted 31 December 2018

Available online 18 January 2019

\section{JEL classification:}

G12

F36

C32

\section{Keywords:}

Gas-exporting countries

Time-varying integration

ICAPM

Risk premium

DCC-GJR-GARCH

\begin{abstract}
A B S T R A C T
This study examines the fundamental driving forces of stock market integration with particular emphasis on major Gas-Exporting Countries (hereafter known as GECs), namely the United Arab Emirates, Qatar, Venezuela, Saudi Arabia, Russia, and Kuwait, over the period from June 2003 to November 2017. The novelty of our study stems from the fact that we examine a dynamic process of international, regional and national stock markets integration using a set of local, regional, global and commodities as driving forces of integration. Particularly, we measure market integration using gas price as a common source of risk in addition to the world, regional and domestic sources of risk based on a conditional version of the International Capital Asset Pricing Model (ICAPM). Our study also differs from past ones in that we investigate the integration of stock markets into the international market as well as in the GECs countries. Our results show that the level of market integration of the major gas-exporting countries varies widely over time and depends on the interest rate spread, the level of market openness and market volatility. It also seems to be still significantly segmented from both the global and GECs markets. Gas risk represents a small part of the global risk in all the countries considered in this study.
\end{abstract}

(c) 2019 Elsevier B.V. All rights reserved.

\section{Introduction}

There is strong evidence that the international economic landscape has changed since the 1980s due to the liberalization of financial markets. We can enumerate a long list of financial crises, such as the crash of the U.S. equity market in 1987, the loan collapse and credit crisis in the end of 1990, the financial crisis in Asia region in 1997, the Enron incident in 2002, the 2007 sub-prime crisis in the U.S. and the 2008 sub-prime crisis. Notably, the sub-prime crisis of mid-2006 was followed by an upsurge of crises and a sharp decline in housing prices in other economies and caused the global financial crisis in 2007. The global financial crisis initiated with the bursting of the U.S. housing crises and has caused some new questions about probable susceptibility to contagion effects. The U.S. tremors

\footnotetext{
* Corresponding author.

E-mail address: julien.chevallier@ipag.fr (J. Chevallier).
}

and shocks play a better role, as its economy is the largest in the world, and its propagation throughout the world. It seems that the global financial crisis has spread to other parts of the world. There seems to be a significant degree of co-movement between different and distant countries. These almost parallel developments provide evidence in favor of a significant correlation across national markets and approve that the U.S. market continues to retain its place as the world's first leading economy.

This paper mainly examines the dynamics of gas-exporting countries' stock market integration into the world market by developing an International Capital Asset Pricing Model (ICAPM), while taking into account gas prices as a potential source of risk. More precisely, we consider an augmented asset-pricing model to analyze the dynamics of equity market integration from 2003 to 2017 conditioned by domestic, regional and global information variables. This issue is of paramount importance because modeling the risk exposure of equity market only by its interdependence with the international market portfolio in the context of an ICAPM might not 
be free of bias. The main reason is that domestic equity markets are not fully integrated into the regional international markets and that the level of market integration is continuing and may be reversed, and more importantly, its determinants are not known in advance. In what follows, we examine the dynamics of gas-exporting countries' stock market integration into the world market. This study departs from that of Bekaert and Harvey (1995) and Carrieri et al. (2007) by developing an international capital asset pricing framework which takes into account gas price as a potential source of risk.

We take the stance to consider gas prices as a potential source of risk, by arguing that the natural gas price has a potential impact on financial market integration. Following the North American shale gas boom around 2005, the influence of natural gas on the global economy has become indeed very substantial. Ji et al. (2018a,b,c,d,e, forthcoming-a,f) suggest that the importance of natural gas has also proliferated in the recent past given the increasing concern for energy security and the desire for cleaner energy sources due to climate change. However, as the number of its main importers such as Japan and China is rising, the socio-economic, as well as political realities in the main exporters such as USA and Russia, have created uncertainties in the international energy market (Zhang and Ji, 2018). These uncertainties which mainly revolves around gas pricing as an essential market signal has attracted a growing body of empirical studies seeking to unravel what drives natural gas prices as well as the interaction between natural gas and international asset prices (see e.g. Acaravci et al., 2012; Ji and Zhang, forthcoming; Ji et al., 2018a,b,c,d,e, forthcoming-a,f).

The Gas Exporting Countries Forum (GECF) was created in 2001 with headquarters in Doha and currently has twelve members (as listed in the comparative table with OPEC in the Appendix). The forum meets the same objectives as OPEC, i.e., strengthening the trading of gas in order to defend the interests of natural gas exporters globally. The GECF allows its members to anticipate the evolution of the natural gas market collectively and develop the exploitation of natural gas in an economically and environmentally cost-efficient way. However, unlike the OPEC, the GECF does not consider itself a cartel, given that it does not enforce production quotas on its members. At a glance, we notice that this forum gathers two-thirds of proven reserves of natural gas, including the three leading producers of natural gas in the world (Iran, Russia, and Qatar). As Liquefied Natural Gas (LNG) producers, the USA is not a member of the forum while seven other countries ${ }^{1}$ are given observatory roles in the forum. Given the intrinsic characteristics of the GECF region, it appears interesting to investigate its dynamics.

The remainder of the article is organized as follows. Section 2 contains the literature review and our contribution. Section 3 presents the empirical approach we use to identify the determinants of financial integration and examine the dynamics of regional financial integration for our sample markets. Section 4 describes the data and their statistical properties. Section 5 reports and discusses the obtained results. Section 6 provides some concluding remarks.

\section{Related literature}

Prior empirical studies agree that the level of stock market integration varies over time (see, e.g., Bekaert and Harvey, 1995; Carrieri et al., 2007; Guesmi and Nguyen, 2011, 2014). Empirical results are, however, divergent regarding the identification procedure of determinant factors of integration. (Bekaert and Harvey $(1995,1997)$, Adler and Qi (2003), and Hardouvelis et al. (2006) arbitrary selected financial and macroeconomic variables to model the logistic function of market integration, while after the estimation of the degree of

\footnotetext{
1 Namely: Angola, Azerbaijan, Iraq, Kazakhstan, Norway, Oman, and Peru.
}

stock market integration, Carrieri et al. (2007) identify 'ex-post' the determinant factors of financial integration. More recently Guesmi and Nguyen (2014) identify the financial integration determinants in four major markets in Southeast Europe by introducing the candidate factors of market integration one by one in the logistic function. As Bhattacharya and Daouk (2002), they impose the estimation results from the multivariate GARCH to guarantee, for all individual markets, the same prices of risk related to regional market and exchange rates. The method proposed by Guesmi and Nguyen (2014) may be subject to criticism because it introduces information variables to assess financial integration one by one. This procedure leads to some loss of efficiency because the process does not consider the interaction of all variables considered.

More so, whereas the influence of oil price on stock markets of regional markets through different channels including returns and volatility has been well documented in recent times (see e.g. Sadorsky, 2001; El-Sharif et al., 2005; Basher and Sadorsky, 2006; Park and Ratti, 2008; Apergis and Miller, 2009; Chen, 2010; Arouri et al., 2011; Arouri et al., 2012; Zhang, 2017; Gomez-Gonzalez et al., 2018; Ji et al., 2018a,b,c,d,e, forthcoming-a,f). Other studies have examined the relationship between energy prices by linking oil, coal and natural gas prices with the stock market (e.g. Wei, 2003; Scholtens and Boersen, 2011; Gatfaoui, 2016; Ji et al., 2018a,b,c,d,e, forthcoming-a,f) and with emphasis on the stock prices of energy companies (e.g. Sardorsky, 2001; Oberndorfer, 2009; Ji and Zhang, forthcoming). Attention has also been given to the connectedness and spillover between oil and natural gas prices (see e.g. Ewing et al., 2002; Brown and Yücel, 2008; Hartley et al., 2008; Ramberg and Parsons, 2012; Atil et al., 2014; Zhang and Ji, 2018; Zhang et al., 2018).

However, despite the growing influence of natural gas on the international energy market, to our best knowledge, only the study by Acaravci et al. (2012) has examined the long run relationship between gas prices and stock prices for 15 European Union countries from the first quarter of 1990 to the first quarter of 2008. Their empirical findings show a long-term relationship between natural gas prices, industrial production, and stock prices in Austria, Denmark, Finland, Germany, and Luxembourg. However, no relationship was found between these variables for Belgium, France, Greece, Ireland, Italy, Netherlands, Portugal, Spain, Sweden, and the UK. The Granger Causality test indicates an inverse relationship between the two variables. The focus on natural gas prices is also particularly desirable given that gas markets are primarily regional and a good understanding of its linkages with the stock markets will guide policymakers' decisions and could have a profound influence on the process of regional financial integration.

Our study contributes to the expanding literature on the interaction between energy and the financial markets by examining the time-varying stock market integration of major Gas-Exporting Countries (hereafter known as GECs), as well as their determinants in the context of a dynamically integrated ICAPM. We seek to find the level of market integration using a set of global and local information variables. To do this, we integrate the price of gas as part of the global risk premium, and we decompose the total risk premium to dictate the contributions of gas risk to the total risk premium. Our study also contributes to the literature on energy finance by examining the dynamic level of international and regional market integration among GECs. Unlike previous studies, we first attempt to identify ex-ante the driving forces behind the integration process of national stock markets using a set of local, regional, global variables and commodities in a dynamic factor model. We also consider in addition to the systematic risks associated with regional and local markets, currency risk which according to theories of international asset pricing models is a relevant factor in pricing equity markets (Adler and Dumas, 1983; Pavlova and Rigobon, 2007; Carrieri et al., 2007; Tai, 2007, Ji et al., 2018a,b,c,d,e, forthcoming-a,f). 


\section{Empirical strategy}

Our model creation stems from an augmented version of the asset price model by Bekaert and Harvey (1995) where the excess return $\mathrm{E}_{t-1}\left(R_{i, t}\right)$ issued in country $i$, conditionally on a set of information available to investors up to time $t-1$ is given by:

$$
\begin{aligned}
\mathrm{E}_{t-1}\left(R_{i, t}\right)= & \omega_{t-1}^{w}\left[\delta_{t-1}^{w} \operatorname{Cov}\left(R_{i, t}, R_{w, t} \mid \Omega_{t-1}\right)\right. \\
& +\delta_{t-1}^{p} \operatorname{Cov}\left(R_{i, t}, R_{P, t} \mid \Omega_{t-1}\right) \\
& +\delta_{t-1}^{G} \operatorname{Cov}\left(R_{i, t}, R_{G, t} \mid \Omega_{t-1}\right) \\
& \left.+\sum_{k^{\prime}=1}^{L^{\prime}} \delta_{k, t-1} \operatorname{Cov}\left(R_{i, t}, R_{k, t} \mid \Omega_{t-1}\right)\right] \\
& +\left(1-\omega_{t-1}^{w}\right) \delta_{i, t-1} \operatorname{Var}_{t-1}\left(R_{i, t} \mid \Omega_{t-1}\right)
\end{aligned}
$$

Let:

$$
\begin{aligned}
& \omega_{t-1}^{W}=\exp \left(-\left|\alpha_{0}+\alpha_{i} F_{i, t-1}\right|\right) \\
& \delta_{t-1}^{W}=\exp \left(\lambda_{w}^{\prime} F_{w, t-1}\right), \\
& \delta_{k, t-1}=\exp \left(\lambda_{k}^{\prime} F_{w, t-1}\right), \\
& \delta_{t-1}^{P}=\exp \left(\lambda_{P}^{\prime} F_{w, t-1}\right), \\
& \delta_{t-1}^{G}=\exp \left(\lambda_{G}^{\prime} F_{w, t-1}\right), \\
& \delta_{i, t-1}=\exp \left(\lambda_{i}^{\prime} F_{i, t-1}\right) .
\end{aligned}
$$

$\mathrm{E}_{t-1}\left(R_{i, t}\right)$ is the excess return in country $i$, conditionally on a set of information $\Omega_{t-1}$ available to investors up to time $t-1$. $\operatorname{Cov}_{t-1}$ is the conditional covariance. $\omega_{t-1}^{w}$ is the conditional probability of transition between segregation and integration states, which falls within the interval of $[0,1]$. In other words, this is a conditional measure of integration of market $i$ respectively into the world market.

This conditional probability depends on integration factors. If $\omega_{i, t-1}^{W}=0$, the unique source of symmetric risk is the variance, and the pricing relationship in a strictly segmented market applies. If $\omega_{i, t-1}^{W}=1$, only the world covariance risk is priced. So the strict world segmentation hypotheses are rejected.

The loading variables $\delta_{t-1}^{W}$ refers to the conditionally expected price of covariance risk and $\delta_{i, t-1}$ refers to the conditionally expected local price. $\delta_{t-1}^{P} \operatorname{Cov}\left(R_{i, t}, R_{p, t} / \Omega_{t-1}\right)$ takes into account the conditional covariance between the security $r$ return and the rewards for GECF region, that is $R_{p, t} . \delta_{t-1}^{G} \operatorname{Cov}\left(R_{i, t}, R_{G, t} / \Omega_{t-1}\right)$ takes into account similar to the previous one between the security $r$ return and the rewards for Gas prices risk, that is $R_{G, t}$. These three loading variables depend on respectively the vector of international information $\left(F_{W, t-1}\right.$, the vector of domestic information $\left(F_{i, t-1}\right.$, at the time $(t-1)$.

Given that the natural gas market which facilitates the trading of natural gas as a commodity has region-specific characteristics and that the deregulation of the intermediaries and spot markets makes it even more complex, we demonstrate the suitability of our model by linking the local stock markets with the price of gas. Gas price risks are managed through the trading of gas contracts in the financial gas market. Also, since the region is composed of the countries that export gas, our model also incorporates the covariance of the stock markets with the international market, as well as the covariance of the region with the international market. Therefore, we argue that gas markets can have a broader international appeal, rather than a purely regional approach.

The subindex $k$ denotes the currencies of GECF countries. This term includes the covariance with the return on the exchange rate of the currency of country $k$, denoted by the variance $R_{k, t}$, against the currency of the reference country. $\delta_{k, t-1}$ expresses the expected price of the exchange rate risk for currency $k$, conditionally on the information available up to $t-1$. $L$ is respectively the number of GECF markets included. We consider the U.S. as the reference country. Finally, $\operatorname{Var}_{t-1}\left(R_{i, t}\right)$ is the conditional variance of the national market return.

The fundamental assumptions of this model, as in Carrieri et al. (2007), are that the continually changing world market structure (i.e., from the state of strictly segmented markets to that state of full integration), as well as the increasing availability of substitute assets, is well captured. The model also assumes the existence of cross-border risk preferences, as well as costs/barriers on the free flow of capital, that is widely accepted as a significant contributor to imperfectly integrated global capital markets. Lastly, it also assumes consistency with the well-known phenomenon of home asset bias.

Eq. (1) can be written as a risk premium decomposition as follows:

$R P_{i, t}^{T}=R P_{i, t}^{W}+R P_{i, t}^{L}+R P_{i, t}^{G}+R P_{i, t}^{P}+R P_{i, t}^{K}$

where $R P_{i, t}^{w}$ and $R P_{i, t}^{L}$ are the world and local premium respectively. $R P_{i, t}^{P}$ and $R P_{i, t}^{G}$ are the GECF region risk and Gas premium respectively. Under the hypothesis of rational expectations, the econometric specification of Eqs. (1)-(2) can be further characterized by the following system of Eqs. (3) to (6). More precisely, the econometric specification of the model to be estimated, i.e., Eqs. (3), (4), and (5), is characterized by the following system of equations:

$$
\begin{aligned}
& \tilde{r}_{W, t}=\delta_{t-1}^{W} h_{W, W, t}+\delta_{t-1}^{p} h_{i, W, t}+\delta_{t-1}^{G} h_{i, G, t}+\sum_{k=1}^{L} \delta_{k, t-1} h_{W, k, t}+\varepsilon_{W, t} \\
& \tilde{r}_{k, t}=\sum_{k^{\prime}=1}^{L^{\prime}} \delta_{i, k, t-1} h_{i, k, t}+\varepsilon_{k, t}
\end{aligned}
$$

$$
\begin{aligned}
\tilde{r}_{i, t}= & \omega_{t-1}^{W}\left[\delta_{t-1}^{W} h_{i, W, t}+\delta_{t-1}^{p} h_{i, W, t}+\delta_{t-1}^{G} h_{i, G, t}+\sum_{k=1}^{L} \delta_{k, t-1} h_{i, k, t}\right] \\
& +\left(1-\omega_{t-1}^{W}\right) \delta_{i, t-1} h_{i, i, t}+\varepsilon_{i, t}
\end{aligned}
$$

$\varepsilon_{t} \mid \Omega_{t-1} \sim N\left(0, H_{t}\right) ; \quad$ where $\quad \varepsilon_{t}=\left[\varepsilon_{w, t}, \varepsilon_{k, t}, \varepsilon_{i, t}\right]^{\prime}$.

$\tilde{r}_{t}$ refers to the vector of excess returns which are assumed to be normally distributed. Also, $\varepsilon_{t}$ is a vector of unexpected excess returns given the set of information, and $H_{t}$ is a conditional variancecovariance matrix of excess returns following a Multivariate DCC-GARCH process with $H_{t}=D_{t} R_{t} D_{t}^{\prime} \cdot R_{t}$ is the symmetric matrix of dynamic conditional correlations. $D_{t}$ is a diagonal matrix of conditional standard deviations for each of the return series, obtained from estimating a univariate GARCH process.

At the empirical level, we consider $N$ exchange rate specifications. Since we consider the U.S. as the reference country, we use bilateral real exchange rates to measure the exchange value of local currencies against the U.S. dollar. This specification, being the baseline, permits us to compare our results with those of existing studies. We then use the bilateral real exchange rates expressed in the currency of the largest country in the region regarding GDP. Finally, the real effective exchange rate indices are employed. These different exchange rate specifications enable us to check the robustness of the findings and to justify our choice of reference currency.

The estimation of the vector of unknown parameters is carried out by the Quasi-Maximum Likelihood Estimation (QMLE) method as proposed by Bollerslev and Wooldridge (1992) to avoid the problem 
of non-normality in excess returns. Given the highly nonlinear structure of the model and the large unknown parameters number, the simultaneous estimation of the model is not feasible. So, we follow the prevailing literature, i.e., Hardouvelis et al. (2006), and Guesmi and Nguyen (2011) to estimate the system from Eqs. (4) to (6) in two steps. In the first stage, we estimate a subsystem of equations for excess returns on regional and individual markets, and exchange rates plus the relevant variance-covariance elements. This step allows us to obtain the conditional variances of the regional market and real exchange rate, their conditional covariances as well as the prices of the regional market and exchange rate risks. In the second stage, we estimate the price of local market risk and the time-varying level of integration for each market.

\section{Data}

The dataset includes six stock market indices (the United Arab Emirates, Qatar, Venezuela, Saudi Arabia, Russia, and Kuwait), exchange rates indices and the Gas index. The data are collected over the period from June 2003 to November 2017. All the data are extracted from Thomson Datastream International. We use monthly stock returns in excess of the one-month Eurodollar interest rate, which is considered as a risk-free rate. Monthly stock returns are calculated from stock market indices with dividends reinvested. We resort to monthly industrial production for the six countries (as a GDP proxy). Real exchange rates represent the value of the local currency against the U.S. dollar and are extracted from the IMF's International Financial Statistics (IFS) and the U.S. Federal Reserve databases. The real effective exchange rate index is the geometric average of bilateral real exchange rates among the countries under consideration. Our choice of the local, regional and global instrumental variables set of information variables is centered upon empirical studies which pioneered the model used for this study. Our model is pioneered in Bekaert and Harvey (1995) and Carrieri et al. (2007). These studies used the following set of information local, regional and global information variables such as the U.S. term structure, U.S. treasury bills, world dividend yield, change in exchange rate, local equity return and the risk-free rate, Euro-dollar rate and the ratio of equity market capitalization to GDP. Following these previous studies, we select the following instrumental variables to explain changes in the prices of risks:

- Regional instrumental variables: the dividend yield of the GECF region in excess of the 30-day Eurodollar interest rate (DYR), the return of the GECF market index (RMI).

- Global instrumental variables: they are used to explain changes in the prices of international markets, Brent crude oil index and foreign exchange risk. We choose the following variables: the world market portfolio (Morgan Stanley Capital InternationalMSCI World index) in excess of the 30-day Eurodollar interest rate which is denoted by (IRENT), the variation in the U.S. term premium (USTP) and the return on the S\&P 500 stock market index (RSP).

- Local instrumental variables: They are used to infer the changes in the local price of risk, include the return on the local stock market index in excess of the 30-day Eurodollar interest rate (LRENT), and the variation in the trade-weighted average local inflation rate (INFRT).

- Financialmarketintegration factors: A set of candidate factors that cause the movements in the degree of regional financial integration is chosen based on the findings of previous studies (e.g., Bekaert and Harvey, 1997, 2000; Bhattacharya and Daouk, 2002). Previous empirical results (e.g., Errunza and Padmanabhan, 1988; Bailey and Stulz, 1990; Errunza et al., 1992; Divecha et al., 1992; Bekaert and Urias, 1996; Phylaktis and Ravazzolo, 2005)

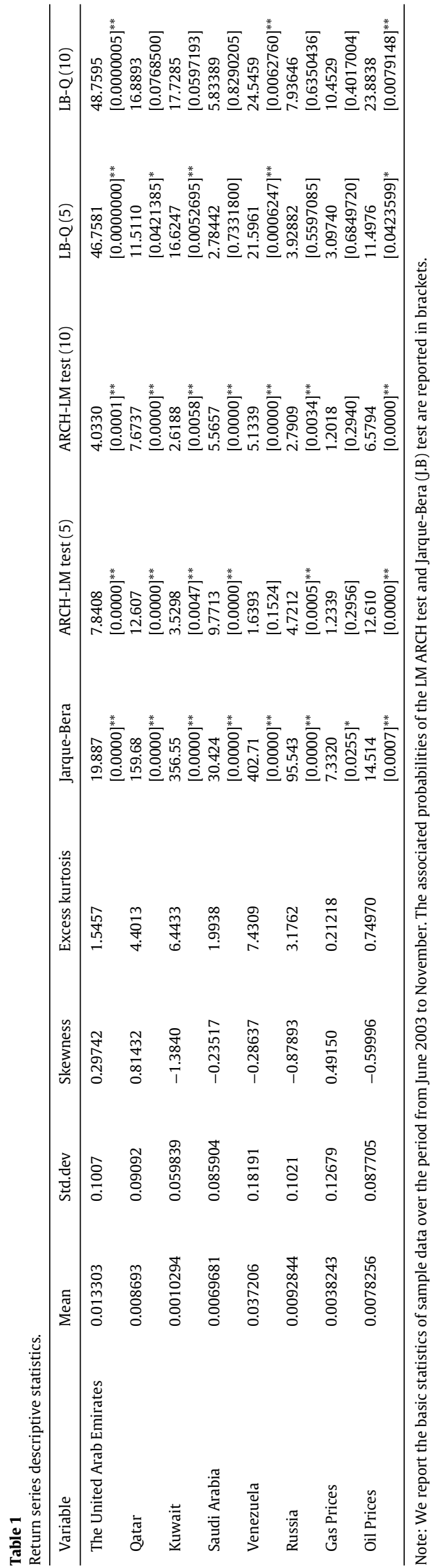


show that, whatever the specification of exchange rate risk, the interest rate spread (SWAY), the level of market openness (OPEN) in each region and The market volatility (denoted VIX) are commonly selected as the relevant factors affecting the regional integration process of the markets under consideration.

Table 1 reports the main statistics of return series for the stock market, real exchange rate and gas for all the countries in the sample. All the series depart from normality conditions and conditional heteroscedasticity. The skewness coefficients are significantly different from zero for almost all markets, indicating the presence of asymmetry in the return distribution. Besides, all the return series are characterized by a kurtosis coefficient statistically significant and greater than 3, and thus have fatter tails than those of a normal distribution. Engle's (1982) test for the 1st order of conditional heteroscedasticity is also performed, and we cannot reject the hypothesis of no ARCH effects for all return series considered. This result motivates our choice of GARCH modeling approach for conditional variance processes.

\section{Results and discussion}

\subsection{Empirical estimates}

As discussed above, we first estimate the system composed of Eqs. (1) to (6) for excess returns on the regional and international markets, gas, and returns on real exchange rates.

In Table 2, Panels A and B present the estimated parameters for the price of gas and international market risk respectively. The price of gas risk is positively correlated with IRENT and positively with RSP (both coefficients being significant at the $1 \%$ level), confirming the co-movement between oil and stock markets, on one side, and diversification opportunities, on the other. The price of international market risk also presents a positive relationship both with IRENT and RSP (in the two cases, the coefficient are significant at $1 \%$ level).

Turning out to the analysis of gas-exporting countries (Panel C), the coefficients associated with the world market portfolio, the S\&P 500 index, and the coefficients associated with the U.S. term premium has a significant effect on the evolution of the price of the exchange rate.

Panel D shows that the coefficients associated with the dividend yield of the GECF region in excess of the 30-day Eurodollar interest rate (DYR) and the return of GECF market index (RMI) are significant at the $1 \%$ level. These variables have a significant positive effect on the evolution of the price of GECF market risk.

In order to examine the relevance of the risk price in the valuation of financial assets issued by the GECF markets, we use the robust Wald test (Table 3 ) to check the nullity of the coefficients associated with the information variables. Consequently, the results from the Wald test reject the hypotheses according to which the risk prices are individually equal to zero. In parallel, the assumptions of the constant world, gas, exchange, and regional risk prices are rejected for the considered markets. These findings are consistent with those of previous studies, including that of Carrieri et al. (2007), Tai (2007), and Guesmi and Nguyen (1995), in the sense that the local risk is a relevant source of risk in the valuation of financial assets issued by GECF markets.

There is a common perception that gas prices, world market, and exchange rate risks influence asset pricing in emerging markets and that they hold profound economic implications in these economies including the GECS countries. For instance, it has become widely accepted that rising gas prices and its volatility (just like oil prices) suppress economic activity and reduce asset prices. Sauter and Awerbuch (2003) argue that energy price shocks reflect a risky obligation for energy consumers to the extent that its prices correlate negatively with economic activity such that peoples' income and asset value decline following a rise in energy prices. On the other hand, gas price risks present severe macroeconomic outcomes

Table 2

Estimation of price risks.

\begin{tabular}{|c|c|c|c|c|}
\hline & Constant & IRENT & USTP & RSP \\
\hline \multicolumn{5}{|c|}{ Panel A: Price of Gas risk } \\
\hline & $\begin{array}{l}0.260^{* * *} \\
(1.065)\end{array}$ & $\begin{array}{l}0.150^{* * *} \\
(0.001)\end{array}$ & $\begin{array}{l}0.130^{* * *} \\
(0.015)\end{array}$ & $\begin{array}{l}0.190^{* * * *} \\
(0.033)\end{array}$ \\
\hline \multicolumn{5}{|c|}{ Panel B: Price of World market risk } \\
\hline & $\begin{array}{l}0.120^{* * * *} \\
(0.011)\end{array}$ & $\begin{array}{l}0.112^{* * *} \\
(0.078)\end{array}$ & $\begin{array}{l}0.023 \\
(0.022)\end{array}$ & $\begin{array}{l}0.788^{* * *} \\
(0.065)\end{array}$ \\
\hline \multicolumn{5}{|c|}{ Panel C: Price of Exchange Rate risk } \\
\hline The & 0.920 & 0.247 & 0.920 & 0.247 \\
\hline United & $(0.598)$ & $(0.689)$ & $(0.592)$ & $(0.680)$ \\
\hline Qnabr & $0.564^{* * *}$ & $0.247^{* * *}$ & $0.567^{* * *}$ & 0.331 \\
\hline Emi- & $(0.056)$ & $(0.089)$ & $(0.027)$ & $(0.089)$ \\
\hline \multirow[t]{2}{*}{ Katesait } & $0.033^{* * *}$ & $0.585^{*}$ & $0.290^{* * *}$ & $0.753^{* * *}$ \\
\hline & $(0.008)$ & $(0.072)$ & $(0.024)$ & $(0.020)$ \\
\hline Saudi & $0.0774^{* * *}$ & $0.037^{* * *}$ & $0.046^{* * *}$ & $0.873^{* * *}$ \\
\hline Ara- & $(0.0084)$ & $(0.002)$ & $(0.002)$ & $(0.006)$ \\
\hline \multirow[t]{2}{*}{ bienezuela } & $-1.600^{* * *}$ & $0.946^{* * *}$ & $0.361^{* * *}$ & $0.699^{* * *}$ \\
\hline & $(0.076)$ & $(0.082)$ & $(0.029)$ & $(0.167)$ \\
\hline \multirow[t]{3}{*}{ Russia } & $-1.600^{* * *}$ & $0.946^{* * *}$ & $0.361^{* * *}$ & $0.528^{* * *}$ \\
\hline & $(0.076)$ & $(0.082)$ & $(0.029)$ & $(0.088)$ \\
\hline & Constant & DYR & RMI & \\
\hline \multicolumn{5}{|c|}{ Panel D: Price of Regional risk } \\
\hline & $0.121^{* * *}$ & $0.089^{* * *}$ & $0.291^{* * *}$ & \\
\hline & $(0.122)$ & $(0.001)$ & $(0.015)$ & \\
\hline
\end{tabular}

Note: This table shows the determinants of exchange rate, world and regional market risk prices. ${ }^{*},{ }^{* *}$, and ${ }^{* * *}$ indicate significance at the $10 \%, 5 \%$ and $1 \%$ rates respectively. 
Table 3

Specification tests of price risks.

\begin{tabular}{|c|c|c|}
\hline & $\chi^{2}$ & $p$-Value \\
\hline \multicolumn{3}{|l|}{ Specification test of prices of World risk } \\
\hline Is the world risk price null? $-H_{0}: \lambda_{i}=0$ & $44.312^{* * *}$ & 0.000 \\
\hline Is the world risk price constant? $-H_{0}: \lambda_{i}=1$ & $851.97^{* * *}$ & 0.000 \\
\hline \multicolumn{3}{|l|}{ Specification test of prices of Gas risk } \\
\hline Is the gas risk price null? $-H_{0}: \lambda_{i}=0$ & $25.152^{* * *}$ & 0.000 \\
\hline Is the gas risk price constant? $-H_{0}: \lambda_{i}=1$ & $633.87^{* * *}$ & 0.000 \\
\hline \multicolumn{3}{|l|}{ Specification test of prices of Exchange Rate risk } \\
\hline Are the prices of the exchange rate risks jointly null? $H_{0}: \lambda_{i}=0$ & $44.312^{* *}$ & 0.000 \\
\hline Are the prices of the exchange rate risks jointly constant? $H_{0}: \lambda_{i}=1$ & $34.078^{* * *}$ & 0.000 \\
\hline \multicolumn{3}{|l|}{ Specification test of prices of Regional risk } \\
\hline Is the GECF risk price null? $-H_{0}: \lambda_{i}=0$ & $55.312^{* *}$ & 0.000 \\
\hline Is the GECF risk price constant? $-H_{0}: \lambda_{i}=1$ & $49.078^{* * *}$ & 0.000 \\
\hline
\end{tabular}

for gas exporters like the GECF countries. The price risks of gas impacts on the fiscal and monetary measures of these economies through volatility in government earnings and cost-push inflationary pressure.

Further, there are several channels through which exposure to the world market and exchange rate risks impact on the economic outcome of emerging markets. Increasing integration with the global financial markets implies a more rapid international transmission of risks resulting in changes in cash flows and current account imbalances. For instance, Granger et al. (2000) note that as stock markets become increasingly integrated with the global market, changes in stock prices result in both capital movements across markets and current account imbalances. On the other hand, exchange rate risks directly influence the international competitiveness of firms given their impact on input and output prices (Nathan, 2002). Thus, note that exchange rate volatility entails real economic costs, affects prices, firms' profitability as well as the general financial stability (Benita and Lauterbach, 2007), holding both positive and negative implications in both export-dominant and import-dominant economies (Ma and Kao, 1990).

We, therefore, decide to use these factors to estimate the degree of regional integration. This restriction allows us to avoid the numerical convergence problem when the number of explanatory variables for integration is above two. In practice, we have attempted to estimate our model with different numbers of market integration determinants, but the specification with two factors (trade openness and local market development) does not face convergence problem and provides the best fit to the data as witnessed by the AIC, BIC and Log-likelihood criteria.

Table 4 reports the obtained results as well as the basic integration measure statistics estimated for the six countries. Overall, the results confirm the identification of driving factors for integration as its dynamics is significantly explained by the selected variables whatever the market is.

Further, Table 4 shows our empirical estimation of the degree of integration using interest rates spread, level of market openness and market volatility show that these factors are relevant in the process of regional integration of the GECS. The result shows that these factors are significant across all the countries except the measure of market openness for the United Arab Emirates and Qatar. This result holds some economic implications for these economies. First, the degree of market openness indicates that the stock markets are increasingly becoming open within the region such that stocks and equity capital can smoothly flow within the markets. However, this also implies that idiosyncratic risks can easily be transmitted to the regional market, thus influencing macroeconomic stability in the region. For instance, stock prices have been found to relate to key macroeconomic factors including consumer prices, growth, and industrial production. For instance, Gilchrist et al. (2009) found that shocks emanating from the bond markets influence key economic variables such as inflation, interest rate, and other financial indicators, causing the significant and persistent contraction to economic activity.

Secondly, the market volatility and interest rate spread are significant across all the economies considered. This shows that these

Table 4

Dynamics of stock market integration.

\begin{tabular}{lllllll}
\hline & The United Arab Emirates & Qatar & Kuwait & Saudi Arabia & Venezuela & Russia \\
\hline Constant & $0.289^{* * *}$ & $0.367^{* * *}$ & $0.197^{* * *}$ & $0.189^{* * *}$ & $1.067^{* * *}$ & $0.463^{* * *}$ \\
& $(-0.022)$ & $(-0.101)$ & $(-0.089)$ & $(-0.011)$ & $(-0.009)$ & $(-0.029)$ \\
OPEN & 0.112 & $-0.102^{* * *}$ & $-0.053^{* * *}$ & $-0.056^{* * *}$ & $0.218^{* * *}$ & $0.055^{* * *}$ \\
& $(-0.125)$ & $(-0.213)$ & $(-0.01)$ & $(-0.028)$ & $(-0.005)$ & $(-0.008)$ \\
SWAY & $-0.020^{* * *}$ & $-0.067^{* * *}$ & $-0.033^{* * *}$ & -0.001 & $0.0774^{* * *}$ & $0.037^{* * *}$ \\
& $(0.011)$ & $(0.003)$ & $(0.002)$ & $(0.011)$ & $(0.0084)$ & $(0.002)$ \\
VIX & $-0.122^{* * *}$ & $-0.348^{* * *}$ & $0.290^{* * *}$ & $-0.141^{* * *}$ & $-1.600^{* * *}$ & $0.946^{* * *}$ \\
& $(0.028)$ & $(0.000)$ & $(0.000)$ & $(0.002)$ & $(0.076)$ & $(0.082)$ \\
$\Omega$ mean & $0.268^{+++}$ & $0.230^{+++}$ & $0.197^{+++}$ & $0.358^{+++}$ & $0.061^{+++}$ & $0.137^{+++}$ \\
$\Omega$ max & 0.397 & 0.362 & 0.373 & 0.467 & 0.152 & 0.245 \\
$\Omega$ min & 0.071 & 0.059 & 0.030 & 0.166 & 0.001 & 0.099 \\
Std. dev. & 0.083 & 0.084 & 0.081 & 0.066 & 0.001 \\
\hline
\end{tabular}

Note: $\Omega \max , \Omega \min$, and $\Omega$ mean indicate the maximum, minimum and average values of market integration measure. ${ }^{*},{ }^{* *}$, and ${ }^{* * *}$ indicate that the coefficients are significant at the $10 \%, 5 \%$ and $1 \%$ levels respectively. ${ }^{+++}$indicates that the average degree of integration is significantly different from zero at the $1 \%$ level with respect to the two-sided Student- $t$ test. 

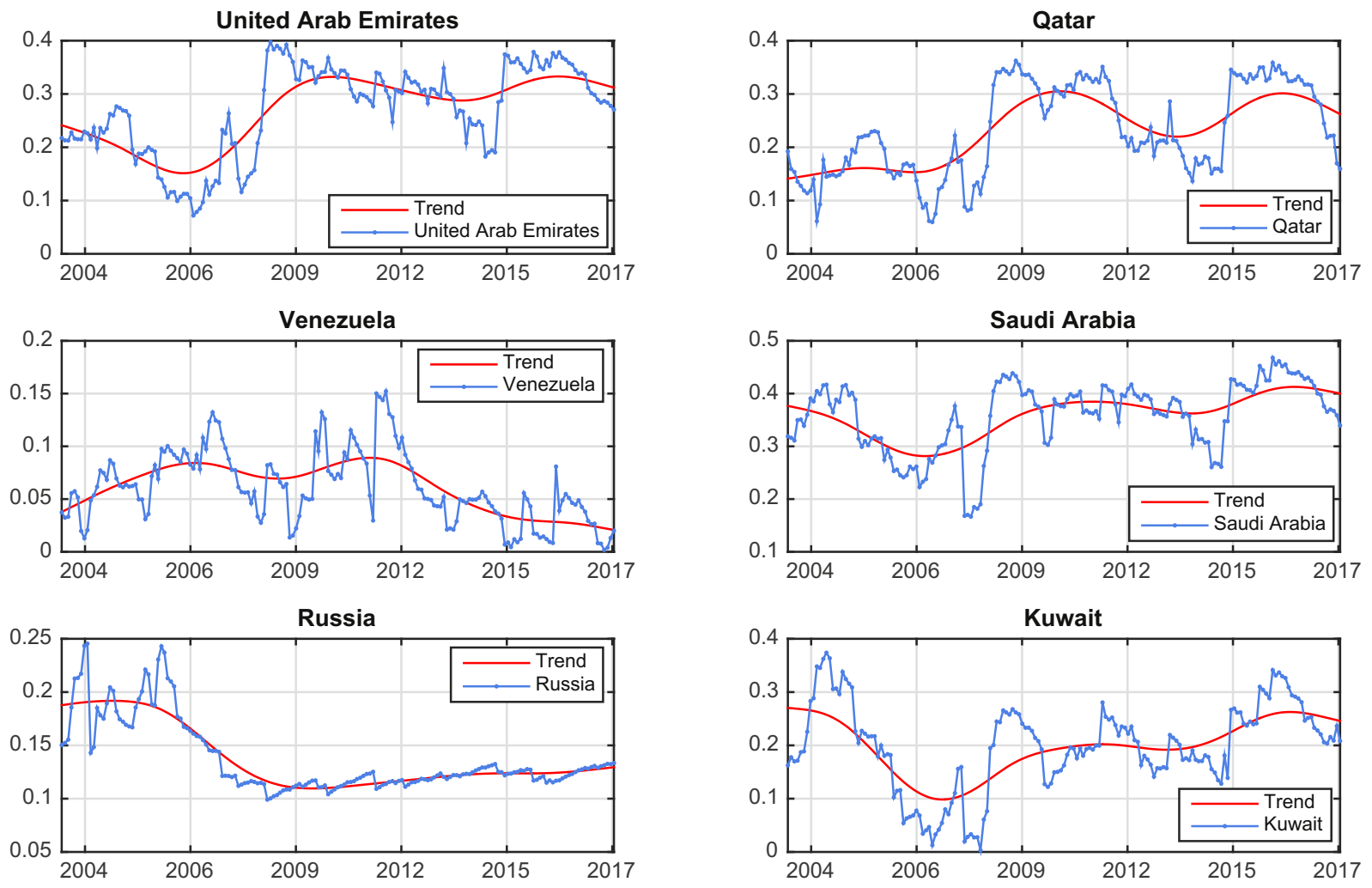

Fig. 1. Level of market integration among gas-exporting countries.

are influential factors that account for the degree of market integration in the GECS region. This implies that these economies face a high risk of macroeconomic volatility following the transmission of shocks both from global and regional sources through their capital markets. Volatility has been variously documented to influence growth negatively, reducing economic welfare, especially, in emerging economies. Loayza et al. (2007) opine that high macroeconomic instability in emerging economies is caused by several factors, notably large external shocks, and that volatility represents a direct welfare cost for risk-averse individuals and an indirect cost through its negative influence on income growth and development.

Lastly, interest rate spread also influences the process of regional integration and is significant across all the economies. Interest rate spread represents the difference between the interest paid by banks to depositors and the interest paid to the bank by the borrowers. The spread largely influences the process of regional financial market integration and impacts upon domestic economies within the region. For instance, although it may not imply utterly perfect mobility of capital within a region, competition lowers the interest differentials and improves access to capital to the extent that domestic monetary policy becomes less effective in the management of interest rates. Were and Wambua (2014) note that as a benefit of financial integration, narrowing interest rate spread reflects critical domestic issues including the efficiency of the financial intermediaries, profitability, monetary policy impacts and the overall level of financial development.

Fig. 1 presents the time-path of our measure for the level of financial market integration (estimates and Hodrick-Prescott filtered values) among the gas-exporting countries in our sample over the period from 2003 to 2017. The trend suggests that the degree of international integration varies over time and differs from one country to another, depicting the divergence in monetary and economic policies of these countries. The degree of market integration was at the highest level in Saudi Arabia, the United Arab Emirates and Qatar (0.4) followed by Kuwait (above 0.3) in 2015. It was highest in Venezuela (0.15) in 2011 and Russia (0.25) in 2004-06. In about all the countries, a downward trend is discernable following a sharp fall in the level of market integration in 2007, but this was followed almost instantly by a quick rise throughout 2008 to 2009. This pattern can also be observed in most of the countries between 2013 and 2015. Lastly, the degree of market integration displays a downward trend since 2016 in all countries. The values found for gas-exporting (e.g., GEC) countries in this study are typically lower than that documented by Créti and Guesmi (2015) regarding the integration of oil-exporting (e.g., OPEC) countries into world markets. ${ }^{2}$

Table 5 reports average values of the total, the global, regional, gas and local risk premiums. The two-sided Student- $t$ test indicates that different risk premiums are significantly different from zero at the $1 \%$ level for all the markets considered. Saudi Arabia has the highest total risk premium (13.365\%), followed by Venezuela (10.952\%), Kuwait (9.485\%), the United Arab Emirates (8.464\%) and Qatar (6,547\%). International risk premiums are on average higher than local and regional premiums for all markets. The share of local risk premium over the total risk premium ranges from $10 \%$ for Russia to $25 \%$ for the United Arab Emirates. Gas risk represents a small part of the global risk for all countries. Gas risk represents however only $10 \%$ of total risk.

The risk premium represents an incremental return required by stockholders for choosing risky stocks instead of risk-free or average risky securities (Dimson et al., 2003). Harris and Marston (1999) note that it is a crucial factor in asset allocation, helping portfolio managers in the determination of the optimal portfolio mix of debt

\footnotetext{
2 The authors display integration measures average between 0.712 (Venezuela) and 0.847 (Kuwait).
} 
Table 5

Decomposition of the total risk premium.

\begin{tabular}{|c|c|c|c|c|c|c|}
\hline & $R P_{i, t}^{T}$ & $R P_{i, t}^{G}$ & $R P_{i, t}^{L}$ & $R P_{i, t}^{K}$ & $R P_{i, t}^{W}$ & $R P_{i, t}^{P}$ \\
\hline The United Arab Emirates & $8,464^{* * *}$ & $0,238^{* * *}$ & $2,365^{* * *}$ & $-0,742^{* * *}$ & $4,382^{* * *}$ & $2,221^{* * *}$ \\
\hline Qatar & $6,547^{* * *}$ & $-0,071^{* * *}$ & $1,435^{* * *}$ & $-0,638^{* * *}$ & $2,23^{* * * *}$ & $3,591^{* * *}$ \\
\hline Kuwait & $9,485^{* * * *}$ & $0,067^{* * *}$ & $2,142^{* * *}$ & $-0,183^{* * *}$ & $3,447^{* * * *}$ & $4,012^{* * * *}$ \\
\hline Saudi Arabia & $13,365^{* * *}$ & $-0,728^{* * *}$ & $2,256^{* * *}$ & $0,141^{* * *}$ & $5,475^{* * *}$ & $6,221^{* * * *}$ \\
\hline Venezuela & $10,592^{* * *}$ & $0,658^{* * *}$ & $1,892^{* * *}$ & $0,124^{* * *}$ & $1,897^{* * *}$ & $6,021^{* * *}$ \\
\hline Russia & $6,409^{* * *}$ & $0,023^{* * *}$ & $0,897^{* * *}$ & $0,028^{* * *}$ & $2,564^{* * *}$ & $2,897^{* * *}$ \\
\hline
\end{tabular}

Note: ${ }^{* * *}$ indicates that the average risk premiums are significantly different from zero at the $1 \%$ level with respect to the two-sided Student- $t$ test. $R P_{i, t}^{W}$ and $R P_{i, t}^{L}$ are respectively the world and local risk premium. $R P_{i, t}^{P}$ and $R P_{i, t}^{G}$ are respectively the GECF region risk premium and Gas risk premium.

and equity and asset pricing. The fundamental assumption in financial analysis suggesting that as long as there is sufficient quality data, extrapolation based on historical risk premium always gives an unbiased estimate of future premium makes the understanding of risk premium very critical in portfolio management. The decomposition of total risk premium in our result above suggest that the risks premium of the GECF have high significant global and regional influence. The implication is that stock markets in these economies are becoming increasingly integrated, both within the region and with the global markets. Hence, their stocks are being traded in the regional capital markets, and therefore belong to internationally integrated markets.

\subsection{Policy implications}

To summarize the gist of our results, we document that the level of market integration among the major gas-exporting countries depends on the interest rate spread, the level of market openness and market volatility. Also, gas-exporting countries seem still significantly segmented from both the global and GECs markets. Overall, the specific gas risk represents a small part of the global risk in all the countries considered in this study.

Risk premium analysis is particularly relevant in the GECF and other emerging markets for several reasons including that it is the driver of equity returns and it determines the cost of capital. This is because the process of market integration often occurs with lower expected returns, thus reducing the cost of capital (Bekaert and Harvey, 1995). Interestingly, increasing market liberalization in emerging economies implies that portfolio managers are faced with improved risk-sharing opportunities. Given that risk drives investment returns, a portfolio mix of debts and stocks from the regional and global capital markets could improve portfolio performance. This corroborates with the critical factor behind portfolio management that diversification with foreign and regional securities that contain assets that have low correlation substantially reduces portfolio risk. A low-risk tolerant portfolio mix would, however, include more debt and equity from the domestic financial markets with similar returns, thus reducing the exposure of the portfolio to regional and global risks. This is because the portfolio theory argues that investors are risk-averse. Our empirical results reveal that the level of market integration of significant gas-exporting countries varies widely over time and depends on the interest rate spread, the level of market openness and market volatility. Besides, we find that gas risk constitutes a small part of the global risk in all countries. The implication is that gas-exporting countries are still primarily segmented from the world and the regional markets.

We would express optimism that our findings have profound implication for policy making in these countries as well as in the process of regional integration. Particularly, given the lack of information about institutional reforms or data that accurately captures its effects especially for countries like Venezuela and Russia as at the time of writing this paper, we would recommend that future research should take into account the impact of institutional reforms aimed at lowering barriers to portfolio flows within the region.

For investors, understanding the interaction between gas prices and the stock market is particularly important as it would guide market decisions concerning the trading of financial assets especially gas contracts. Besides, given the risk associated with the increasing financialization of commodities, these findings would be helpful in risk management and portfolio diversification strategies using gas commodity and its derivatives.

For regional policy makers in GECF, these findings are significant in the pricing of natural gas given that the GECF influences the market for gas. Our findings would also be valuable in the process of policy formulation towards regional integration of gas exporters. Generally, our research offers an innovative and universal perspective for considering the integration process and the transmission mechanisms of risks within the region and across the global market. However, given the lack of information about institutional reforms or data that accurately captures its effects especially for countries like Venezuela and Russia as at the time of writing this paper, we would recommend that future research should take into account the impact of institutional reforms aimed at lowering barriers to portfolio flows within the region.

\section{Conclusion}

In this paper, given the growing influence of natural gas price in the energy market and its implications for the stock markets of significant gas exporters and the potential impact on financial market integration, we examined the dynamics of gas-exporting countries' stock market integration into the world market. We underline the predominant role played by the natural gas price in energy markets, especially since the shale gas revolutionary technique has been widely adopted in the U.S. and other regions of the world (e.g., Argentina, Canada, China, Poland, see for instance the IEA website ${ }^{3}$ ).

It has been widely documented that the degree of integration of many countries varies over time. Whereas it is expected that market integration continuously increases over time, the reality is that the level of integration could halt or even reverse depending on certain variables including market volatility, currency exchange rates and barriers to portfolio flows. The empirical estimation of the degree of market integration is however tricky, prompting most previous studies to make the three key assumptions of strict segmentation, full integration, and partial integration - where integration is assumed to remain constant over time (Bekaert and Harvey, 1995).

However, following Bekaert and Harvey (1995) which offers an innovative econometric approach in the estimation of the evolution of market integration in emerging markets in the context of a

\footnotetext{
3 https://www.iea.org/ugforum/ugd/shalegas/.
} 
regime-switching methodology, a growing body of empirical studies have emerged in this subject. The international asset pricing models adopted in these studies have been severally modified to account for different local and international information variables that affect the degree of market integration. For instance, Carrieri et al. (2007) incorporated measures of financial market development and liberalization policies and found that there are important factors that affect the degree of market integration in emerging markets.

This study departs from that of Bekaert and Harvey (1995) and Carrieri et al. (2007) by developing an international capital asset pricing framework which takes into account gas prices as a potential source of risk. In its fully functional form, the model allows the market integration measure as well as global, regional, local and gas risk premiums to vary over time. Following this framework, we also examine the time-variations in expected returns on stock market indices.

Our empirical results reveal that the level of market integration of important gas-exporting countries varies widely over time and depends on the interest rate spread, the level of market openness and market volatility. Also, we find that gas risk constitutes a small part of the global risk in all countries. The implication is that gasexporting countries are still primarily segmented from the world and the regional market. We would express optimism that our findings have profound implication for policy making in these countries as well as in the process of regional integration. Notably, we would recommend that future research should take into account the impact of institutional reforms aimed at lowering trade barriers which affect capital movements.

\section{Acknowledgements}

For constructive comments and feedback, we wish to thank Dayong Zhang, Qiang Ji, anonymous reviewers, as well as seminar participants at the 2018 International Conference on Energy Finance: Frontiers and Future Development, Institutes of Science and Development (Chinese Academy of Sciences, Beijing, China), and the 2018 International Symposium on Environment and Energy Finance (IPAG Business School, France).

\section{Appendix A}

Table 6

Comparative list of membership in Oil \& Gas cartels.

\begin{tabular}{|c|c|c|}
\hline & OPEC & GECF \\
\hline \multicolumn{3}{|l|}{ Middle-East } \\
\hline Saudi Arabia & $\mathrm{X}$ & \\
\hline Iran & $X$ & $\mathrm{X}$ \\
\hline Iraq & $\mathrm{X}$ & \\
\hline The United Arab Emirates & $\mathrm{X}$ & $\mathrm{X}$ \\
\hline Qatar & $\mathrm{X}$ & $\mathrm{X}$ \\
\hline Kuwait & $\mathrm{X}$ & \\
\hline \multicolumn{3}{|l|}{ Africa } \\
\hline Egypt & & $\mathrm{X}$ \\
\hline Libya & $\mathrm{X}$ & $\mathrm{X}$ \\
\hline Nigeria & $\mathrm{X}$ & $\mathrm{X}$ \\
\hline Angola & $\mathrm{X}$ & \\
\hline Algeria & $\mathrm{X}$ & $\mathrm{X}$ \\
\hline Guinea & & $\mathrm{X}$ \\
\hline \multicolumn{3}{|l|}{ South America } \\
\hline Ecuador & $\mathrm{X}$ & \\
\hline Venezuela & $\mathrm{X}$ & $\mathrm{X}$ \\
\hline Bolivia & & $\mathrm{X}$ \\
\hline Trinidad and Tobago & & $\mathrm{X}$ \\
\hline Russia & & $\mathrm{X}$ \\
\hline
\end{tabular}

\section{Appendix B. Supplementary data}

Supplementary data to this article can be found online at https:// doi.org/10.1016/j.eneco.2018.12.027.

\section{References}

Acaravci, A., Ozturk, I., Kandir, S.Y., 2012. Natural gas prices and stock prices: evidence from EU-15 countries. Econ. Model. 29 (5), 1646-1654.

Adler, M., Dumas, B., 1983. International portfolio selection and corporation finance: a synthesis. J. Financ. 38, 925-984.

Adler, M., Qi, R., 2003. Mexico's integration into the North American capital market. Emerg. Mark. Rev. 4, 91-120.

Apergis, N., Miller, S.M., 2009. Do structural oil-market shocks affect stock prices? Energy Econ. 31 (4), 569-575.

Arouri, M.E.H., Lahiani, A., Nguyen, D.K., 2011. Return and volatility transmission between world oil prices and stock markets of the GCC countries. Econ. Model. 28 (4), 1815-1825.

Arouri, M.E.H., Jouini, J., Tuyen, N., Nguyen, D.C., 2012. On the relationship between world oil prices and GCC stock markets. J. Quant. Econ. 10 (1), 98-120.

Atil, A., Lahiani, A., Nguyen, D.K., 2014. Asymmetric and nonlinear pass-through of crude oil prices to gasoline and natural gas prices. Energy Policy 65, 567-573.

Bailey, W., Stulz, R.M., 1990. Benefits of international diversification: the case of Pacific Basin stock markets. J. Portf. Manag. 16 (4), 57-61.

Basher, S.A., Sadorsky, P., 2006. Oil price risk and emerging stock markets. Glob. Financ. J. 17 (2), 224-251.

Bekaert, G., Harvey, C.R., 1995. Time-varying world market integration. J. Financ. 50, 403-444.

Bekaert, G., Harvey, C.R., 1997. Emerging equity market volatility. J. Financ. Econ. 43 (1), 29-77.

Bekaert, G., Harvey, C.R., 2000. Foreign speculators and emerging equity Markets. J. Financ. 55, 565-613.

Bekaert, G., Urias, M.S., 1996. Diversification, integration and emerging market closed-end funds. J. Financ. 51 (3), 835-869.

Benita, G., Lauterbach, B., 2007. Policy factors and exchange rate volatility. Int. Res. J. Financ. Econ. 7 (8).

Bhattacharya, U., Daouk, H., 2002. The world price of insider trading. J. Financ. 57, 75-108.

Bollerslev, T., Wooldridge, J.M., 1992. Quasi-maximum likelihood estimation and inference in dynamic models with time-varying covariances. Econ. Rev. 11, $143-172$.

Brown, S.P., Yücel, M.K., 2008. What drives natural gas prices? Energy J. 29 (2), 45-60.

Carrieri, F., Errunza, V., Hogan, K., 2007. Characterizing world market integration through time. J. Financ. Quant. Anal. 42, 915-940.

Chen, S.S., 2010. Do higher oil prices push the stock market into bear territory? Energy Econ. 32 (2), 490-495.

Créti, A., Guesmi, K., 2015. International CAPM and Oil price: evidence from selected OPEC countries. Bank. Mark. Invest. (136-137), 64-78.

Dimson, E., Marsh, P., Staunton, M., 2003. Global evidence on the equity risk premium. J. Appl. Corp. Financ. 15 (4), 27-38.

Divecha, A.B., Drach, J., Stefek, D., 1992. Emerging markets: a quantitative perspective. J. Portf. Manag. 19 (1), 41-50.

El-Sharif, I., Brown, D., Burton, B., Nixon, B., Russell, A., 2005. Evidence on the nature and extent of the relationship between oil prices and equity values in the UK. Energy Econ. 27 (6), 819-830.

Engle, R., 1982. Autoregressive conditional heteroskedasticity with estimates of the variance of U.K Inflation. Econometrica 50, 987-1008.

Errunza, V., Losq, E., Padmanabhan, P., 1992. Tests of integration, mild segmentation and segmentation hypotheses. J. Bank. Financ. 16 (5), 949-972.

Errunza, V.R., Padmanabhan, P., 1988. Further evidence on the benefits of portfolio investments in emerging markets. Financ. Anal. J. 44 (4), 76-78. Jul.

Ewing, B.T., Malik, F., Ozfidan, O., 2002. Volatility transmission in the oil and natural gas markets. Energy Econ. 24 (6), 525-538.

Gatfaoui, H., 2016. Linking the gas and oil markets with the stock market: investigating the US relationship. Energy Econ. 53, 5-16.

Gilchrist, S., Yankov, V., Zakrajšek, E., 2009. Credit market shocks and economic fluctuations: evidence from corporate bond and stock markets. J. Monet. Econ. 56 (4), 471-493.

Gomez-Gonzalez, J.E., Hirs-Garzon, J., Sanin-Restrepo, S., 2018. Dynamic relations between oil and stock markets: volatility spillovers, networks, and causality. Borradores de Economía., pp. 1-20. No. 1051.

Granger, C.W., Huang, B.N., Yang, C.W., 2000. A bivariate causality between stock prices and exchange rates: evidence from recent Asian flu. Q. Rev. Econ. Finance 40 (3), 337-354

Guesmi, K., Nguyen, D.N., 2011. How strong is the global integration of emerging market regions? An empirical assessment. Econ. Model. 28, 2517-2527.

Guesmi, K., Nguyen, D.N., 2014. Time-varying regional integration of stock markets in Southeast Europe. Appl. Econ. 46 (11), 1279-1290.

Hardouvelis, G.A., Malliaropulos, D., Priestley, R., 2006. EMU and European stock market integration. J. Bus. 79, 365-373.

Harris, R.S., Marston, F.C., 1999. The market risk premium: expectational estimates using analysts' forecasts. Darden Business School Working Paper No. 99-08. 
Hartley, P.R., Medlock, K.B., III, Rosthal, J., 2008. The relationship of natural gas to oil prices. Energy J. 29 (3).47-45.

Ji, Q., Bouri, E., Roubaud, D., 2018a. Dynamic network of implied volatility transmission among US equities, strategic commodities, and BRICS equities. Int. Rev. Financ. Anal. 57, 1-12.

Ji, Q., Bouri, E., Roubaud, D., Shahzad, S.J.H., 2018b. Risk spillover between energy and agricultural commodity markets: a dependence-switching CoVaR-copula model. Energy Econ. 75, 14-27.

Ji, Q., Geng, J.B., Tiwari, A.K., 2018c. Information spillovers and connectedness networks in the oil and gas markets. Energy Econ. 75, 71-84.

Ji, Q., Zhang, D., Geng, J.B., 2018d. Information linkage, dynamic spillovers in prices and volatility between the carbon and energy markets. J. Clean. Prod. 198, 972-978.

Ji, Q., Zhang, H.Y., Geng, J.B., 2018e. What drives natural gas prices in the United States? A directed acyclic graph approach. Energy Econ. 69, 79-88.

Ji, Q., Liu, B.Y., Fan, Y., 2018. Risk dependence of covar and structural change between oil prices and exchange rates: a time-varying copula model. Energy Econ.forthcoming.

Ji, Q., Liu, B.Y., Zhao, W.L., Fan, Y., 2018. Modeling dynamic dependence and risk spillover between all oil price shocks and stock market returns in the BRICS. Int. Rev. Financ. Anal.forthcoming.

Ji, Q., Zhang, D., 2018. China's crude oil futures: introduction and some stylized facts. Financ. Res. Lett.forthcoming.

Loayza, N.V., Ranciere, R., Servén, L., Ventura, J., 2007. Macroeconomic volatility and welfare in developing countries: an introduction. World Bank Econ. Rev. 21 (3), 343-357.

Ma, C.K., Kao, G.W., 1990. On exchange rate changes and stock price reactions. J. Bus. Financ. Acc. 17 (3), 441-449.

Nathan, L.J., 2002. Modelling the impacts of interest rate and exchange rate changes on UK stock returns. J. Deriv. Hedge Funds 7 (4), 306.

Oberndorfer, U., 2009. Energy prices, volatility, and the stock market: evidence from the Eurozone. Energy Policy 37 (12), 5787-5795.
Park, J., Ratti, R.A., 2008. Oil price shocks and stock markets in the U.S. and 13 European countries. Energy Econ. 30, 2587-2608.

Pavlova, A., Rigobon, R., 2007. Asset prices and exchange rates. Rev. Financ. Stud. 20 (4), 1139-1180.

Phylaktis, K., Ravazzolo, F., 2005. Stock market linkages in emerging markets: implications for international portfolio diversification. J. Int. Financ. Mark. Inst. Money 15 (2), 91-106.

Ramberg, D.J., Parsons, J.E., 2012. The weak tie between natural gas and oil prices. Energy J. 33 (2), 13-35.

Sadorsky, P., 2001. Risk factors in stock returns of Canadian oil and gas companies Energy Econ. 23 (1), 17-28.

Sauter, R., Awerbuch, S., 2003. Oil price volatility and economic activity: a survey and literature review. IEA Research Paper. 28. pp. 550-577.

Scholtens, B., Boersen, A., 2011. Stocks and energy shocks: the impact of energy accidents on stock market value. Energy 36 (3), 1698-1702.

Tai, C.S., 2007. Market integration and contagion: evidence from Asian emerging stock and foreign exchange markets. Emerg. Mark. Rev. 8, 264-283.

Wei, C., 2003. Energy, the stock market, and the putty-clay investment model. Am. Econ. Rev. 93 (1), 311-323.

Were, M., Wambua, J., 2014. What factors drive interest rate spread of commercial banks? Empirical evidence from Kenya. Rev. Dev. Financ. 4 (2), 73-82.

Zhang, D., 2017. Oil shocks and stock markets revisited: measuring connectedness from a global perspective. Energy Econ. 62, 323-333.

Zhang, D., Ji, Q., 2018. Further evidence on the debate of oil-gas price decoupling: a long memory approach. Energy Policy $113,68-75$.

Zhang, D., Shi, M., Shi, X., 2018. Oil indexation, market fundamentals, and natural gas prices: an investigation of the Asian premium in natural gas trade. Energy Econ. 69, 33-41. 